\title{
Probiotics and Upper Respiratory Tract - a Review
}

\section{Tapiovaara, Laura}

2016-07

Tapiovaara , L , Pitkäranta , A I \& Korpela , R 2016 , ' Probiotics and Upper Respiratory

Tract - a Review ' , Pediatric Infectious Disease Journal , vol. 1 , no. 3 , 19 . https://doi.org/10.4172/PIDO.100019

http://hdl.handle.net/10138/175832

https://doi.org/10.4172/PIDO.100019

publishedVersion

Downloaded from Helda, University of Helsinki institutional repository.

This is an electronic reprint of the original article.

This reprint may differ from the original in pagination and typographic detail.

Please cite the original version. 


\title{
Probiotics and the Upper Respiratory Tract - A Review
}

\author{
Laura Tapiovaara ${ }^{1 *}$, Anne Pitkaranta ${ }^{1}$ and Riitta Korpela ${ }^{2}$ \\ ${ }^{1}$ Department of Otorhinolaryngology-Head and Neck Surgery, Helsinki University Hospital, University of Helsinki, Helsinki, Finland \\ ${ }^{2}$ Faculty of Medicine, Pharmacology, Medical Nutrition Physiology, University of Helsinki, Helsinki, Finland
}

*Corresponding author: Laura Tapiovaara, Department of Otorhinolaryngology-Head and Neck Surgery, Helsinki University Hospital, University of Helsinki, Helsinki, Finland, Email: laura.k.tapiovaara@helsinki.fi

Received date: June 24, 2016; Accepted date: July 12, 2016; Published date: July 18, 2016

Citation: Tapiovaara L, Pitkaranta A, Korpela R (2016) Probiotics and the Upper Respiratory Tract - A Review. Pediatric Infect Dis 1:19. doi: 10.4172/PIDO.100019

Copyright: (C) 2016 Tapiovaara L, et al. This is an open-access article distributed under the terms of the Creative Commons Attribution License, which permits unrestricted use, distribution, and reproduction in any medium, provided the original author and source are credited.

\section{Introduction}

The interest in gut micro biota has emerged in recent decades. Gut micro biota has been associated with the promotion of health, the increased the risk of disease, and the maintenance of some diseases. Upper respiratory infections caused by viruses are among the most common health problems in humans [1]. In addition to the misery of sickness, these infections result in a significant burden on society in terms of healthcare visits, absences from work, and reduced school attendance. In addition, unnecessary medical costs are incurred. The careless use of antibiotics during respiratory tract infections has resulted in the constantly growing resistance of microbes to antibiotics [2]. The complications of upper respiratory infections, such as otitis and sinusitis, also result in high expenses and expose patients to potentially harmful operations. If viral upper respiratory infections could be prevented and treated, these outlays would be minimized.

According to a panel of international experts, "probiotics are live microorganisms that, when administered in adequate amounts, confer a health benefit on the host" $[3,4]$. The strain should be precisely defined (i.e., identified and characterized), the dose should be defined, the health claim should be indicated, and the safety should be assessed. The properties of probiotics vary widely according to the strain. Even the manufacturing process influences the properties of certain strains [5].

Lactobacillus rhamnosus GG (L. GG, ATCC 53103) is one of the most-often studied probiotics. This bacterial strain of human origin has been isolated from the human gut. Its benefits in Gl disorders have been demonstrated [6], and similar effects have been found in upper respiratory infections $[7,8]$. Although the colonization of the gut and the fecal recovery of specific probiotics, including L. GG, have been extensively studied, little information is available on the colonization of the upper respiratory epithelium where the lymphatic system is present. Even less is known about the effects of the possible colonization of the related mucosal tissues.
Probiotics are widely added to commercial dairy products and food products, and they are increasingly consumed as supplements [9]. The safety of L. GG has been monitored since 1989. A few case reports have described infections caused by probiotics, such as bacteremia, endocarditis, and internal organ abscesses. However, the incidence of Lactobacillus bacteremia has remained stable although the consumption of probiotic products has increased exponentially [10]. Infections seem to be very sparse and affect mostly immunocompromised or critically ill patients [11]. Probiotic consumption has been documented as safe in neonates and even in preterm infants [12]. A report from Finland suggested that L. GG is safe for premature infants based on 12 years of its administration to all premature and very low birth weight infants born in the area around one university hospital [13].

\section{Probiotics and their health effects}

Probiotics should fulfil the following criteria: they must survive in the gastrointestinal tract and be able to proliferate in the gut; they should benefit the host through growth and/or activity in humans; and they should be non-pathogenic and non-toxic [14]. Probiotic micro-organisms exist in multiple genus, species, and strains. Although recent evidence suggests that they have some common health effects, they have many strain-specific health effects [4]. The most common probiotic organisms are bacteria from the genus Bifidobacterium and the genus Lactobacilli [15]. The findings of broad metaanalyses of strain-specific probiotics support that common health benefits are derived from consuming an adequate dose of any safe strain of a species that is already known to be an effective probiotic. For example, a meta-analysis of different strains and 10,351 patients found that probiotics had a positive effect on eight gastrointestinal diseases across the all studied probiotic species [16]. However, the results showed differences in efficacy regarding specific diseases and specific differences in strains.

Professional medical organizations have made clinical recommendations of well-defined specific probiotics for specific clinical conditions. In particular, gastrointestinal conditions have shown health effects: probiotics are 
recommended in the treatment and prevention of acute gastroenteritis, necrotizing enterocolitis, and antibioticassociated diarrhea [17]. They can be supplemented with infant formula to enhance growth and improve clinical outcomes although evidence is still lacking [18]. Some evidence exists to support the use of probiotics in several conditions: constipation, irritable bowel syndrome, inflammatory bowel diseases, lactose intolerance, allergies, atopic eczema, certain cancers, hepatic diseases, hyperlipidaemia, Helicobacter pylori infection, genitourinary tract infections, and oral health $[19,20]$. In 2015, the World Allergy Organization (WAO) convened a guideline panel to develop evidence-based recommendations for the use of probiotics in the prevention of allergy [21]. The European Pediatric Gastroenterology, Hepatology and Nutrition (ESPGHAN) association has also established recommendations for the use of probiotics in the prevention and treatment of acute gastroenteritis in children [22]. ESPGHAN recommends the use of specific, well-studied probiotics to prevent and treat acute gastroenteritis in infants and children and to reduce the side-effects associated with antibiotics [22]. In addition, the meta-analysis of a specific probiotic strain concluded that $L$. GG was effective in preventing antibiotic-associated diarrhea in children and adults who were treated with antibiotics for any reason [23].

\section{Mechanisms of action}

The mechanisms of the action of probiotics in viral and bacterial infections are not completely understood. Specific probiotics show strain-specific potential for reinforcing the integrity of the intestinal epithelium and regulating immune components. In regulating complex immune responses, the gastrointestinal tract from the oral cavity to the rectum is considered the largest immune interface with the environment [24]. The potential mechanisms are studied mainly in the gastrointestinal epithelium. Some postulated mechanisms of probiotic action in intestinal epithelial defense are presented in Figure 1, Adapted from Wan et al. [25]. The potential mechanisms of action in the upper respiratory tract remain unknown, and similar mechanisms than in intestinal epithelium may exist, but the topic needs to be studied further.

It is possible that probiotic bacteria could bind to an invading virus, thus inhibiting virus attachment to the host-cell receptor [26]. Lactic acid bacteria may exert antiviral activity by the following: 1) direct interaction as an adsorptive or trapping mechanism; 2) stimulation of the immune system by interleukin, natural killer cells, Th1 immune response activity, and IgA production; 3) production of antiviral agents (e.g., hydrogen peroxide, lactic acid, and bacteriocins) [27].

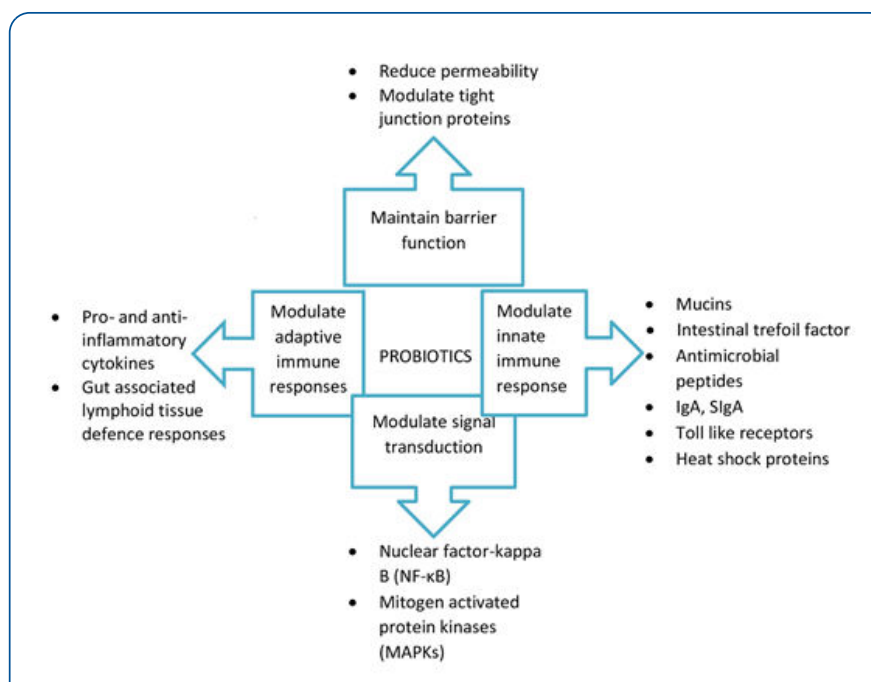

Figure 1: Possible mechanisms by which probiotic bacteria modulate intestinal defence responses

\section{Acute viral respiratory infections}

Acute viral upper respiratory infections (URI), which are also known as the common cold, are among the most common health problems in humans [28]. The economic burden on society of the otherwise usually benign disease is enormous because of absences from work, school, and daycare, as well as the utilization of health care providers and treatments. In the USA, 25 million health care visits a year are made because of URI [29]. On average, children 1-2 years of age experience 3-8 respiratory infections yearly, and children over 5 years of age experience about three respiratory infections yearly $[30,31]$.

More than 200 viruses are known to cause respiratory infections in humans [32]. Major pathogens that induce URIs are human rhinoviruses (HRVs) from the family Picornaviridae, genus Enterovirus [33]. Other common causative agents are respiratory syncytial virus (RSV), parainfluenza virus, enterovirus (EV), coronavirus, influenza virus, and adenovirus [34]. Of these, influenza virus, RSV, and parainfluenza virus are more frequent causes of lower than upper respiratory infections [28,31,35]. The symptoms of URI arise after an incubation period that varies depending on the causative agent.

\section{Colonization of upper respiratory tract with probiotics}

Colonization of the gut epithelium by probiotics has been extensively studied [36-38]. Mucosal adhesion is incorrectly taught as essential for both non-immune and mucosal immune defense mechanisms. For example, noncolonizing probiotics, such as Lactobacillus casei, may exert their functions in a transient manner or by influencing the existing microbial community [39]. Thus far, few trials have investigated the colonization of upper respiratory tract with probiotics. In a pilot study, probiotic Lactobacillus plantarum DSM9843 was 
cultured from the tonsillar surfaces of 6 subjects up to eight hours after the per oral consumption of fermented oatmeal gruel enriched with this probiotic [40]. Another small population trial investigated the recovery of Streptococcus salivarius $\mathrm{K} 12$ in the nasopharynx and oral cavity after oral intake [41]. In this study, one of 19 nasopharyngeal cultures was reported positive for the probiotic, and it was recovered from three adenoids of the seven examined. Tonsillar recovery of L. GG after per oral consumption was studied in 57 young adults in a placebo-controlled and randomized trial [42]. L. GG was recovered in $40 \%$ of the L. GG groups' tonsillar samples and in $30 \%$ of the placebo groups' samples. In a recent trial, 20 adults were treated with intranasal Streptococcus salivarius $24 \mathrm{SMBc}$ for three days [43]. The results showed that $95 \%$ of the subjects were colonized in the nasopharynx with the probiotic at least four hours after spray administration; colonization persisted for at least six days in in 55\% of the subjects. L. GG was also recovered from adenoid tissue of children consuming probiotic per orally in a randomized double-blinded study [44]. Here, all subjects who consumed L. GG presented with the bacteria in the adenoid, as well as $76 \%$ of the placebo groups samples were positive. Twenty-five middle ear effusion samples of the same study population were studied in another trial [45]. In this study, $21 \%$ in the L. GG group presented with L. GG and $7 \%$ in the placebo group presented with L. GG in the middle ear. These studies are presented in Table 1.

Table 1: Characteristics of the previous studies investigating the colonization of upper respiratory tract with probiotics; $\mathrm{RDBPC}=$ randomized, placebo-controlled, prospective clinical trial

\begin{tabular}{|c|c|c|c|c|}
\hline Subjects & Design and duration & Probiotic supplementation & Main findings & Reference \\
\hline $\begin{array}{l}\text { Healthy volunteers, mean age } 38 \\
(n=6)\end{array}$ & $\begin{array}{l}\text { Swab samples from tonsils } \\
\text { after single per oral intake }\end{array}$ & L. plantarum $\left(2 \times 10^{11} \mathrm{cfu}\right)$ & Colonization remained for $8 \mathrm{~h}$ & $\begin{array}{l}\text { Stjernquist-Desatnik } \\
\text { et al. [40] }\end{array}$ \\
\hline $\begin{array}{l}\text { Children } \\
\text { tympanostomy, aged } 0.5-5 \text { years } \\
(n=19)\end{array}$ & $\begin{array}{l}\text { Swab samples from tongue } \\
\text { and nasopharynx, } \\
10 \text { days }\end{array}$ & $\begin{array}{l}\text { S. salivarius } \mathrm{K} 12\left(1.7 \times 10^{10}\right. \\
\mathrm{cfu})\end{array}$ & $33 \%$ colonized & Power et al. [41] \\
\hline $\begin{array}{l}\text { Young adults scheduled for } \\
\text { tonsillectomy, mean age } 24.5 \text { years } \\
(n=57)\end{array}$ & $\begin{array}{l}\text { RDBPC } \\
\text { Tonsil tissue samples, } 3 \\
\text { weeks }\end{array}$ & $\begin{array}{l}\text { L. GG }\left(2 \times 10^{10} \mathrm{cfu}\right) \text { or } \\
\text { multispecies L. GG, Lc705, } \\
\text { PJS, BB12 }\end{array}$ & $\begin{array}{l}30-40 \% \text { colonized NS in } \\
\text { different intervention groups }\end{array}$ & Kumpu et al. [42] \\
\hline $\begin{array}{l}\text { Healthy adults aged } \\
30-54(n=20)\end{array}$ & $\begin{array}{lr}\text { Nasal } & \text { spray, } \\
\text { rhinopharyngeal } & \text { swabs, } 3 \\
\text { days } & \end{array}$ & $\begin{array}{l}\text { S. salivarius } 24 \mathrm{SMBc}(8 \mathrm{x} \\
\left.10^{9} \mathrm{cfu}\right)\end{array}$ & $\begin{array}{l}95 \% \text { colonized } 55 \% \text { remained } \\
\text { for six days }\end{array}$ & Santagati et al. [43] \\
\hline $\begin{array}{l}\text { Children scheduled for adenotomy, } \\
\text { median age } 37,8 \text { mo }(n=31)\end{array}$ & $\begin{array}{l}\text { RDBPC } \\
\text { Adenoid samples, } \\
3 \text { weeks }\end{array}$ & L. $G G\left(8-9 \times 10^{9} \mathrm{cfu}\right) \times 2$ & $\begin{array}{l}100 \% \text { colonized in L. GG } \\
\text { group, } 76 \% \text { in placebo group }\end{array}$ & Swanljung et al. [44] \\
\hline $\begin{array}{lll}\text { Children } & \text { scheduled } & \text { for } \\
\text { tympanostomy, } & \text { median age } 31 \text { mo } \\
(n=13) & \end{array}$ & $\begin{array}{l}\text { RDBPC } \\
\text { MEE samples, } \\
3 \text { weeks }\end{array}$ & L. $G G\left(8-9 \times 10^{9} \mathrm{cfu}\right) \times 2$ & $\begin{array}{l}21 \% \text { colonized in L.GG group, } \\
7 \% \text { in placebo group }\end{array}$ & Tapiovaara et al. [45] \\
\hline
\end{tabular}

\section{Clinical effects of probiotics in the upper respiratory tract}

The prevention of upper respiratory infections by the use of probiotics has been studied in several trials. For instance, L. GG alone or in combination with other probiotics was shown to reduce the incidence or risk of URI in children [46-48]. A recent systematic review found a favourable outcome of the use of probiotics in reducing the episodes of new respiratory infection in children [49]. However, further studies are required to confirm these results. A recent Cochrane database review of the use of probiotics in URI found 13 randomized controlled trials with participants in several age groups [50] (Table 2). Probiotics were found to be better than the placebo in reducing the number of subjects who experienced acute URI, the mean duration of acute URI, the number of antibiotic prescriptions, and cold-related school absences. However, the quality of evidence was considered low or very low.
A meta-analysis of randomized, placebo-controlled trials indicates that $L$. GG is able to reduce the incidence of acute otitis media (AOM) and antibiotic prescriptions and decrease the risk of URI in children [51]. However, in otitis-prone children with nasopharyngeal pathogen colonization, L. GG did not reduce the occurrence of AOM [52]. A novel treatment model of intranasal spray bacteriotherapy with Streptococcus sanguinis was found to be effective in decreasing MEE in children with prolonged otitis media with effusion (OME) [53]. Statistically significant recovery was achieved with Streptococcus sanguinis, and a more modest, yet positive effect was achieved with L. GG. In otitis-prone children, the consumption of L. GG, Lc705, BB99, and PJS significantly reduced the number of positive human bocavirus nasopharyngeal samples [54]. The colonization of the epithelium of the upper respiratory system with specific probiotics or lactic acid bacteria is not well known. Lactobacillus plantarum DSM 9843 was recovered from the tonsillar surface after oral administration, suggesting that the strain may possess the capacity to adhere to tonsillar cells [40]. 
Streptococcus salivarius K12 was cultured from the nasopharynx of infants after the consumption of an oral powder prepared with this probiotic bacterium [41]. Furthermore, L. GG was recovered from tonsil tissue after oral consumption, and prolonged adhesion (over 4 weeks) was suspected [42]. The consequences of colonization are unknown. An in vitro experiment indicates that L. GG is able to inhibit the adherence of Streptococcus pneumoniae to human epithelial cells [55]. Two review studies suggested that specific probiotics interact with pathogens and have the potential to reduce pathogen colonization in the nasopharynx, thus potentially reducing AOM and URI $[26,56]$.

Table 2: Characteristics of the included randomized controlled studies in Hao et al. 2015; RD=randomized, B=placebo-controlled, $\mathrm{P}=$ prospective, $\mathrm{C}=$ clinical trial

\begin{tabular}{|c|c|c|c|c|}
\hline Subjects & Design and duration & Probiotic supplementation & $\begin{array}{l}\text { Main findings: } \\
\text { Probiotic vs. placebo }\end{array}$ & Reference \\
\hline $\begin{array}{l}\text { Healthy adults aged } \\
18-65(n=318)\end{array}$ & RDBPC, 3 month & $\begin{array}{l}\text { L. plantarum and L. paracasei } \\
\left(1 \times 10^{9} \mathrm{cfu}\right)\end{array}$ & $\begin{array}{l}\text { Incidence of common } \\
\text { cold episodes } \downarrow \\
\text { Number of days with } \\
\text { respiratory symptoms } \downarrow\end{array}$ & Berggren et al. [75] \\
\hline Day-care children aged 1-5 $(n=398)$ & RDBC, 3 month & L. rhamnosus HN001 (10 $10 \mathrm{cfu})$ & $\begin{array}{l}\text { Number and duration of } \\
\text { URI } \leftrightarrow \\
\text { Level of secretory } \lg \mathrm{A} \uparrow\end{array}$ & Cáceres et al. [76] \\
\hline $\begin{array}{l}\text { Older volunteers in daycare facilities } \\
(n=154)\end{array}$ & RDBPC, 5 month & $\begin{array}{l}\text { L. casei strain Shirota } \\
\left(4 \times 10^{10} \mathrm{cfu}\right)\end{array}$ & $\begin{array}{l}\text { Number of acute URI } \\
\text { and symptom score } \leftrightarrow\end{array}$ & Fujita et al. [77] \\
\hline $\begin{array}{l}\text { Day-care children aged } 13-86 \text { month } \\
(n=281)\end{array}$ & RDBPC, 3 month & L. rhamnosus GG $\left(10^{9} \mathrm{cfu}\right)$ & $\begin{array}{l}\text { Risk of URI } \downarrow \\
\text { Days with respiratory } \\
\text { symptoms } \downarrow\end{array}$ & Hojsak et al. [7] \\
\hline $\begin{array}{l}\text { Hospitalized in pediatric department, } \\
\text { over 1-year-old }(n=742)\end{array}$ & $\begin{array}{l}\text { RDBPC, duration of } \\
\text { hospitalization }\end{array}$ & L. rhamnosus GG $\left(10^{9} \mathrm{cfu}\right)$ & $\begin{array}{l}\text { Risk of URI } \downarrow \\
\text { Episodes of URI >3 } \\
\text { days } \downarrow\end{array}$ & Hojsak et al. [8] \\
\hline Healthy volunteers aged $69-80(n=60)$ & $\mathrm{RPC}, 2$ or 3 month & $\begin{array}{l}\text { L. bulgaricus }\left(1.8-3.2 \times 10^{10} \mathrm{cfu}\right) \\
\text { and } \mathrm{S} \text {. thermophilus }(5.7-7.9 \times \\
\left.10^{10} \mathrm{cfu}\right)\end{array}$ & $\begin{array}{l}\text { Risk of URI } \downarrow \\
\text { Natural killer cell } \\
\text { activity } \uparrow\end{array}$ & Makino et al. [78] \\
\hline $\begin{array}{l}\text { Healthy day-care or school children } \\
\text { aged } \\
3-6(n=638)\end{array}$ & RDBPC, 3 month & $\begin{array}{l}\text { L. casei }\left(2 \times 10^{10} \text { cfu }\right) \text {, } \\
\text { S.thermophiles and L. bulgaricus } \\
\left(10^{9} \mathrm{cfu}\right)\end{array}$ & $\begin{array}{l}\text { Incidence for common } \\
\text { infectious diseases } \downarrow\end{array}$ & Merenstein et al. [79] \\
\hline $\begin{array}{l}\text { Infants needing formula aged } 0-2 \\
\text { month }(n=81)\end{array}$ & RDBPC, 12 month & $\begin{array}{l}\text { L. rhamnosus and B. lactis } \\
\text { BB-12 }\left(1 \times 10^{10} \mathrm{cfu}\right)\end{array}$ & $\begin{array}{l}\text { Risk of URI } \downarrow \\
\text { Risk of AOM and } \\
\text { antibiotics } \downarrow\end{array}$ & Rautava et al. [47] \\
\hline $\begin{array}{l}\text { Healthy children aged } \\
8-13(n=80)\end{array}$ & RDBPC, 3 month & $\begin{array}{l}\text { L. acidophilus and B. bifidum ( } 1 \\
\left.\times 10^{9} \mathrm{cfu}\right)\end{array}$ & $\begin{array}{l}\text { Symptoms of URI } \downarrow \\
\text { Absences from school } \\
\text { related to URI } \downarrow\end{array}$ & $\begin{array}{l}\text { Rerksuppaphol et al. } \\
{[80]}\end{array}$ \\
\hline Children aged $6-25 \mathrm{mo}(\mathrm{n}=100)$ & RPC, 3 month & $\begin{array}{l}\text { L. acidophilus and L. casei }\left(10^{9}\right. \\
\left.-10^{10} \mathrm{cfu}\right)\end{array}$ & $\begin{array}{l}\text { Episodes of respiratory } \\
\text { tract infections } \downarrow\end{array}$ & Rio et al. [81] \\
\hline $\begin{array}{l}\text { School children aged } \\
3-12 \text { years }(n=251)\end{array}$ & RDBPC, 5 month & L. casei & $\begin{array}{l}\text { Duration of lower } \\
\text { respiratory infections } \downarrow\end{array}$ & Cobo Sanz et al. [82] \\
\hline College students aged $18-24(n=198)$ & RDBPC, 3 month & $\begin{array}{l}\text { L. rhamnosus GG and B. } \\
\text { animalis ssp. lactis BB-12 }\end{array}$ & $\begin{array}{l}\text { Duration or URI } \downarrow \\
\text { Median severity score } \downarrow \\
\text { Missed school days } \downarrow\end{array}$ & Smith et al. [83] \\
\hline $\begin{array}{l}\text { Healthy adults, average age } 38 \pm 13 \\
(n=479)\end{array}$ & RDBPC, 8.5 month & $\begin{array}{l}\text { L. gasseri, } B \text {. longum, and } B \text {. } \\
\text { bifidum }\left(5 \times 10^{7} \mathrm{cfu}\right)\end{array}$ & $\begin{array}{l}\text { Duration of URI } \downarrow \\
\text { Total symptom score } \downarrow \\
\text { Days with fever during } \\
\text { URI } \downarrow\end{array}$ & de Vrese et al. [84] \\
\hline
\end{tabular}

\section{Discussion}

The nasopharyngeal and adenoid micro biota is a complex interactive system, and the consequences of changing the proportions, such as by probiotic colonization, remain unknown. The nasopharynx harbors a wide variety of bacteria and viruses, both commensal and pathogenic [57,58]. The bacterial composition of nasopharyngeal micro biota differs 
from other body parts, which was surveyed in healthy Chinese young adults [59]. The nasopharyngeal micro biota presented with potentially invasive bacteria, such as Streptococcus pneumoniae, $H$. infuenzae, Staphylococcus aureus, $M$. catarrhalis, and Neisseria meningitidis in an overall healthy population $[60,61]$. In children, the nasopharyngeal micro biota was noted to change according to the season [60]. Furthermore, certain commensal taxa were found to be negatively associated with AOM pathogens, and the proportions of taxa changed depending on the use of antibiotics [62]. Respiratory viruses have been shown to accomplish changes in bacterial adhesion [63], colonization [64] and immunological mechanisms [65] in the nasopharynx. Eventually, complex interactions between viruses and bacteria in the nasopharyngeal epithelium can evoke bacterial superinfections [66]

It has been suggested that nasopharyngeal micro biota could affect subjects' vulnerability to respiratory infections. In an experimental HRV challenge trial, significant differences in two nasopharyngeal genera (Neisseria and Propionibacterium) were identified between HRV-infected and non-infected subjects [67]. Furthermore, a previous study showed that young children presented with a small number of bacterial taxa in high total numbers in their nasopharynx, contrary to their parents who presented with much more diverse taxa with lower bacterial carriage [68]. This finding suggests that a greater variety of nasopharyngeal micro biota could protect the subject against URI. It is possible that the maturation of the host-associated microbial community happens similarly in the nasopharyngeal area and in the gut [69]. Interestingly, the development of nasopharyngeal micro biota was studied in 60 healthy infants, and certain micro biota patterns were found to be associated with decreases in URI episodes reported by the parents [70]. Furthermore, nasopharyngeal micro biota, especially Streptococcus, has been implicated to children's risk of developing asthma [71]. These aspects of microbial diversity in the nasopharynx are also considered when breastfeeding is recommended $[70,72]$.

Microbes can adhere directly to each other, but effects can also occur through adhesion on the host's mucosal surfaces. Highly evolved relationships between the upper respiratory micro biota exist, and it is important to understand those interactions, especially when the micro biota is manipulated. In probiotic settings, knowledge of the colonization of the respiratory epithelium is valuable for further research to investigate the effects of probiotics on the natural micro biota.

Over the past decades, gut micro biota has been increasingly recognized as one of the main factors in the increasing prevalence of immunity-related disorders, such as inflammation, atopy, asthma, musculoskeletal disorders, liver fibrosis, diabetes mellitus type 2, metabolic syndrome, cardiovascular diseases, neurodegenerative diseases, atherosclerosis, and cancer, which is also known as the hygiene hypothesis [73]. The research on metagenomics has contributed information on how the micro biota interacts with the host's physiology and has started to provide new therapeutically targets. Finally, by better understanding the role of gut micro biota, the individual's micro biota could be integrated into personalized healthcare, and the individual's diseases could be targeted and treated more efficiently. However, the complete understanding of the disease process is required to determine whether targeting gut micro biota would be effective or not [74].

\section{Funding}

The study is funded by the Sal We research program GET IT DONE (Tekes, the Finnish Funding Agency for Technology and Innovation, grant number 3986/31/2013).

\section{Competing Interests}

All authors declare any competing interests.

\section{References}

1. Fendrick AM, Monto AS, Nightengale B, Sarnes M (2003) The economic burden of non-influenza-related viral respiratory tract infection in the United States. Arch Intern Med 163: 487-494.

2. Roca I, Akova M, Baquero F, Carlet J, Cavaleri M, et al. (2015) The global threat of antimicrobial resistance: science for intervention. New Microbes New Infect 6: 22-29.

3. WHO/FAO (2001) Health and nutritional properties of probiotics in food including powder milk with live lactic acid bacteria report of a Joint FAO/WHO Expert Consultation on Evaluation of Health and Nutritional Properties of Probiotics in Food Including Powder Milk with Live Lactic Acid Bacteria, CÃ ${ }^{3}$ rdoba, Argentina, pp: 1-4.

4. Hill C, Guarner F, Reid G, Gibson GR, Merenstein DJ, et al. (2014) Expert consensus document. The International Scientific Association for Probiotics and Prebiotics consensus statement on the scope and appropriate use of the term probiotic. Nat Rev Gastroenterol Hepatol 11: 506-514.

5. GrzeÅ)kowiak Å, Isolauri E, Salminen S, Gueimonde M (2011) Manufacturing process influences properties of probiotic bacteria. Br J Nutr 105: 887-894.

6. Vitetta L, Briskey D, Alford H, Hall S, Coulson S (2014) Probiotics, prebiotics and the gastrointestinal tract in health and disease. Inflammopharmacology 22: 135-154.

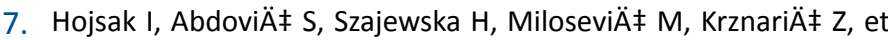
al. (2010) Lactobacillus GG in the prevention of nosocomial gastrointestinal and respiratory tract infections. Pediatrics 125 : e1171-1177.

8. Hojsak I, Snovak N, Abdoviäł S, Szajewska H, Misak Z, et al. (2010) Lactobacillus GG in the prevention of gastrointestinal and respiratory tract infections in children who attend day care centers: a randomized, double-blind, placebo-controlled trial. Clin Nutr 29: 312-316.

9. Siró I, Kápolna E, Kápolna B, Lugasi A (2008) Functional food. Product development, marketing and consumer acceptance-a review. Appetite 51: 456-467.

10. Salminen MK, Tynkkynen S, Rautelin H, Saxelin M, Vaara M, et al. (2002) Lactobacillus bacteremia during a rapid increase in probiotic use of Lactobacillus rhamnosus GG in Finland. Clin Infect Dis 35: $1155-1160$. 
11. Boyle RJ, Robins-Browne RM, Tang ML (2006) Probiotic use in clinical practice: what are the risks? Am J Clin Nutr 83: 1256-1264.

12. AlFaleh K, Anabrees J (2013) Efficacy and safety of probiotics in preterm infants. See comment in PubMed Commons below J Neonatal Perinatal Med 6: 1-9.

13. Luoto R, Isolauri E, Lehtonen L (2010) Safety of Lactobacillus GG probiotic in infants with very low birth weight: twelve years of experience. Clin Infect Dis 50: 1327-1328.

14. Wassenaar TM, Klein G (2008) Safety aspects and implications of regulation of probiotic bacteria in food and food supplements. $J$ Food Prot 71: 1734-1741.

15. Guarner F, Khan AG, Garisch J, Eliakim R, Gangl A (2012) World Gastroenterology Organization World Gastroenterology Organisation Global Guidelines: probiotics and prebiotics October 2011. J.Clin.Gastroenterol 46: 468-481.

16. Ritchie ML, Romanuk TN (2012) A meta-analysis of probiotic efficacy for gastrointestinal diseases. PLoS One 7: e34938.

17. Ebner S, Smug LN, Kneifel W, Salminen SJ, Sanders ME (2014) Probiotics in dietary guidelines and clinical recommendations outside the European Union. World J Gastroenterol 20: 16095-16100.

18. Braegger C, Chmielewska A, Decsi T, Kolacek S, Mihatsch W, et al. (2011) Supplementation of infant formula with probiotics and/or prebiotics: a systematic review and comment by the ESPGHAN committee on nutrition. J Pediatr Gastroenterol Nutr 52: 238-250.

19. Brown AC, Valiere A (2004) Probiotics and medical nutrition therapy. Nutr Clin Care 7: 56-68.

20. Kopp-Hoolihan L (2001) Prophylactic and therapeutic uses of probiotics: a review. J Am Diet Assoc 101: 229-238.

21. Fiocchi A, Pawankar R, Cuello-Garcia C, Ahn K, Al-Hammadi S, et al. (2015). World Allergy Organization-McMaster University Guidelines for Allergic Disease Prevention (GLAD-P): Probiotics. World Allergy Organ J 8: 4.

22. Szajewska H, Guarino A, Hojsak I, Indrio F, Kolacek S, et al. (2014) European Society for Pediatric Gastroenterology, Hepatology, and Nutrition Use of probiotics for management of acute gastroenteritis: a position paper by the ESPGHAN Working Group for Probiotics and Prebiotics. J PediatrGastroenterol Nutr 58: 531-539.

23. Szajewska H, Kolodziej M (2015) Systematic review with metaanalysis: Lactobacillus rhamnosus GG in the prevention of antibiotic-associated diarrhoea in children and adults. Aliment Pharmacol Ther 42: 1149-1157.

24. MacDonald TT, Monteleone I, Fantini MC, Monteleone G (2011) Regulation of homeostasis and inflammation in the intestine. Gastroenterology 140: 1768-1775.

25. Wan LY, Chen ZJ, Shah NP, El-Nezami H (2015) Modulation of Intestinal Epithelial Defense Responses by Probiotic Bacteria. Crit Rev Food Sci Nutr.

26. Salminen S, Nybom S, Meriluoto J, Collado MC, Vesterlund S, et al. (2010) Interaction of probiotics and pathogens--benefits to human health? Curr Opin Biotechnol 21: 157-167.

27. Al Kassaa I, Hober D, Hamze M, Chihib NE, Drider D (2014) Antiviral potential of lactic acid bacteria and their bacteriocins. Probiotics Antimicrob Proteins 6: 177-185.

28. Heikkinen T, Järvinen A (2003) The common cold. Lancet 361: 51-59.
29. Gonzales R, Malone DC, Maselli JH, Sande MA (2001) Excessive antibiotic use for acute respiratory infections in the United States. Clin Infect Dis 33: 757-762.

30. Wald ER, Guerra N, Byers C (1991) Upper respiratory tract infections in young children: duration of and frequency of complications. Pediatrics 87: 129-133.

31. Nokso-Koivisto J, Hovi T, PitkÃ ranta A (2006) Viral upper respiratory tract infections in young children with emphasis on acute otitis media. Int J Pediatr Otorhinolaryngol 70: 1333-1342.

32. Eccles R (2005) Understanding the symptoms of the common cold and influenza. Lancet Infect Dis 5: 718-725.

33. Fendrick AM (2003) Viral respiratory infections due to rhinoviruses: current knowledge, new developments. Am J Ther 10: 193-202.

34. Passioti M, Maggina P, Megremis S, Papadopoulos NG (2014) The common cold: potential for future prevention or cure. Curr.Allergy Asthma Rep 14: 413.

35. Mäkelä MJ, Puhakka T, Ruuskanen $O$, Leinonen $M$, Saikku $P$, et al. (1998) Viruses and bacteria in the etiology of the common cold. J Clin Microbiol 36: 539-542.

36. Alander M, Satokari R, Korpela R, Saxelin M, Vilpponen-Salmela T, et al. Persistence of colonization of human colonic mucosa by a probiotic strain, Lactobacillus rhamnosus GG, after oral consumption. Appl Environ.Microbiol 65: 351-354.

37. Ramakrishna BS (2009) Probiotic-induced changes in the intestinal epithelium: implications in gastrointestinal disease. Gastroenterol 30: 76-85.

38. Bermudez-Brito M, Plaza-Díaz J, Muñoz-Quezada S, GómezLlorente C, Gil A (2012) Probiotic mechanisms of action. Ann Nutr Metab 61: 160-174.

39. Ohland CL, Macnaughton WK (2010) Probiotic bacteria and intestinal epithelial barrier function. Am J Physiol Gastrointest Liver Physiol 298: 807-819.

40. Stjernquist-Desatnik A, Warfving H, Johansson ML (2000) Persistence of Lactobacillus plantarum DSM 9843 on human tonsillar surface after oral administration in fermented oatmeal gruel. A pilot study. Acta Otolaryngol 543: 215-219.

41. Power DA, Burton JP, Chilcott CN, Dawes PJ, Tagg JR (2008) Preliminary investigations of the colonisation of upper respiratory tract tissues of infants using a paediatric formulation of the oral probiotic Streptococcus salivarius K12. Eur J Clin Microbiol Infect Dis 27: $1261-1263$.

42. Kumpu M, Swanljung E, Tynkkynen S, Hatakka K, Kekkonen RA, et al. (2013) Recovery of probiotic Lactobacillus rhamnosus GG in tonsil tissue after oral administration: randomised, placebocontrolled, double-blind clinical trial. Br J Nutr 109: 2240-2246.

43. Santagati M, Scillato M, Muscaridola N, Metoldo V, La Mantia I, et al. (2015) Colonization, safety, and tolerability study of the Streptococcus salivarius $24 \mathrm{SMBC}$ nasal spray for its application in upper respiratory tract infections. Eur J Clin Microbiol Infect Dis 34: $2075-2080$

44. Swanljung E, Tapiovaara L, Lehtoranta L, Makivuokko H, Roivainen $M$, et al. (2015) Lactobacillus rhamnosus $G G$ in adenoid tissue: Double-blind, placebo-controlled, randomized clinical trial. Acta Otolaryngol 135: 824-830.

45. Tapiovaara L, Lehtoranta L, Swanljung E, Makivuokko H, Laakso S, et al. (2014) Lactobacillus rhamnosus GG in the middle ear after 
randomized, double-blind, placebo-controlled oral administration. Int J Pediatr Otorhinolaryngol 78: 1637-1641.

46. Hatakka K, Savilahti E, Pönkä A, Meurman JH, Poussa T, et al. (2001) Effect of long term consumption of probiotic milk on infections in children attending day care centres: double blind, randomised trial. BMJ 322: 1327.

47. Rautava S, Salminen S, Isolauri E (2009) Specific probiotics in reducing the risk of acute infections in infancy--a randomised, double-blind, placebo-controlled study. Br J Nutr 101: 1722-1726.

48. Kumpu M, Kekkonen RA, Kautiainen $H$, Jarvenpaa $S$, Kristo $A$, et al. (2012) Milk containing probiotic Lactobacillus rhamnosus GG and respiratory illness in children: a randomized, double-blind, placebo-controlled trial. Eur J Clin Nutr 66: 1020-1023.

49. Araujo GV, de Oliveira Junior MH, Peixoto DM, Sarinho ES (2015) Probiotics for the treatment of upper and lower respiratory-tract infections in children: systematic review based on randomized clinical trials. J Pediatr (Rio J) 91: 413-427.

50. Hao Q, Dong BR, Wu T (2015) Probiotics for preventing acute upper respiratory tract infections. Cochrane Database Syst.Rev 2: CD006895.

51. Liu S, Hu P, Du X, Zhou T, Pei X. (2013) Lactobacillus rhamnosus GG supplementation for preventing respiratory infections in children: a meta-analysis of randomized, placebo-controlled trials. Indian Pediatr 50: 377-381.

52. Hatakka K, Blomgren K, Pohjavuori S, Kaijalainen T, Poussa T, et al. (2007) Treatment of acute otitis media with probiotics in otitisprone children-a double-blind, placebo-controlled randomised study. Clin Nutr 26: 314-321.

53. Skovbjerg S, Roos K, Holm SE, Grahn Håkansson E, Nowrouzian F, et al. (2009) Spray bacteriotherapy decreases middle ear fluid in children with secretory otitis media. Arch Dis Child 94: 92-98.

54. Lehtoranta L, Söderlund-Venermo M, Nokso-Koivisto J, Toivola H, Blomgren K, et al. (2012) Human bocavirus in the nasopharynx of otitis-prone children. Int J Pediatr Otorhinolaryngol 76: 206-211.

55. Wong SS, Quan Toh Z, Dunne EM, Mulholland EK, Tang ML, et al. (2013) Inhibition of Streptococcus pneumoniae adherence to human epithelial cells in vitro by the probiotic Lactobacillus rhamnosus GG. BMC Res Notes 6: 135.

56. John M, Dunne EM, Licciardi PV, Satzke C, Wijburg O, et al. (2013) Otitis media among high-risk populations: can probiotics inhibit Streptococcus pneumoniae colonisation and the risk of disease? Eur J Clin Microbiol Infect Dis 32: 1101-1110.

57. Chi DH, Hendley JO, French $P$, Arango $P$, et al. (2003)Nasopharyngeal reservoir of bacterial otitis media and sinusitis pathogens in adults during wellness and viral respiratory illness. Am J Rhinol 17: 209-214.

58. Skevaki CL, Tsialta P, Trochoutsou Al, Logotheti I, Makrinioti $\mathrm{H}$, et al. (2015) Associations Between Viral and Bacterial Potential Pathogens in the Nasopharynx of Children With and Without Respiratory Symptoms. Pediatr Infect Dis J 34: 1296-1301.

59. Ling Z, Liu X, Luo Y, Yuan L, Nelson KE, et al. (2013) Pyrosequencing analysis of the human micro biota of healthy Chinese undergraduates. BMC Genomics 14: 390.

60. Bogaert D, Keijser B, Huse S, Rossen J, Veenhoven R, et al. (2011) Variability and diversity of nasopharyngeal micro biota in children: a metagenomic analysis. PLoS One 6: e17035.

61. Hendley JO, Hayden FG, Winther B (2005) Weekly point prevalence of Streptococcus pneumoniae, Hemophilus influenzae and Moraxella catarrhalis in the upper airways of normal young children: effect of respiratory illness and season. APMIS 113: 213-220.

62. Pettigrew MM, Gent JF, Pyles RB, Miller AL, Nokso-Koivisto J, et al. (2011) Viral-bacterial interactions and risk of acute otitis media complicating upper respiratory tract infection. J Clin Microbiol 49: 3750-3755.

63. Avadhanula V, Rodriguez CA, Devincenzo JP, Wang Y, Webby RJ, et al. (2006) Respiratory viruses augment the adhesion of bacterial pathogens to respiratory epithelium in a viral species- and cell type-dependent manner. J Virol 80: 1629-1636.

64. Tong HH, Weiser JN, James MA, DeMaria TF (2001) Effect of influenza $A$ virus infection on nasopharyngeal colonization and otitis media induced by transparent or opaque phenotype variants of Streptococcus pneumoniae in the chinchilla model. Infect Immun 69: 602-606.

65. Colamussi ML, White MR, Crouch E, Hartshorn KL (1999) Influenza $A$ virus accelerates neutrophil apoptosis and markedly potentiates apoptotic effects of bacteria. Blood 93: 2395-2403.

66. Bakaletz LO (1995) Viral potentiation of bacterial superinfection of the respiratory tract. Trends Microbiol 3: 110-114.

67. Allen EK, Koeppel AF, Hendley JO, Turner SD, Winther B, et al. (2014) Characterization of the nasopharyngeal micro biota in health and during rhinovirus challenge. Microbiome 2: 22.

68. Stearns JC, Davidson CJ, McKeon S, Whelan FJ, Fontes ME, et al. (2015) Culture and molecular-based profiles show shifts in bacterial communities of the upper respiratory tract that occur with age. ISME J 9: 1246-1259.

69. Adlerberth I, Wold AE (2009) Establishment of the gut micro biota in Western infants. See comment in PubMed Commons below Acta Paediatr 98: 229-238.

70. Biesbroek G, Tsivtsivadze E, Sanders EA, Montijn R, Veenhoven $\mathrm{RH}$, et al. (2014) Early respiratory micro biota composition determines bacterial succession patterns and respiratory health in children. Am J Respir Crit Care Med 190: 1283-1292.

71. Teo SM, Mok D, Pham K, Kusel M, Serralha M, et al. (2015) Inouye, $M$. The infant nasopharyngeal microbiome impacts severity of lower respiratory infection and risk of asthma development. Cell Host Microbe 17: 704-715.

72. Berrington JE, Cummings SP, Embleton ND (2014) The nasopharyngeal micro biota: an important window of opportunity. Am J Respir Crit Care Med 190: 246-248.

73. Bubnov RV, Spivak MY, Lazarenko LM, Bomba A, Boyko NV (2015) Probiotics and immunity: provisional role for personalized diets and disease prevention. EPMA J 6: 14.

74. Marchesi JR, Adams DH, Fava F, Hermes GD, Hirschfield GM, et al. (2016) The gut micro biota and host health: a new clinical frontier. Gut 65: 330-339.

75. Berggren A, Lazou Ahren I, Larsson N, Onning G (2011) Randomised, double-blind and placebo-controlled study using new probiotic lactobacilli for strengthening the body immune defence against viral infections. Eur J Nutr 50: 203-210.

76. CÃceres P, Montes S, Vega N, Cruchet S, Brunser O, et al. (2010) Effects of HNOO1 on acute respiratory infections and intestinal secretory IgA in children. 5: 353-362.

77. Fujita R, limuro S, Shinozaki T, Sakamaki K, Uemura Y, et al. (2013) Decreased duration of acute upper respiratory tract infections with daily intake of fermented milk: a multicenter, double- 
blinded, randomized comparative study in users of day care facilities for the elderly population. Am J Infect Control 41: 1231-1235.

78. Makino S, Ikegami S, Kume A, Horiuchi H, Sasaki H, et al. (2010) Reducing the risk of infection in the elderly by dietary intake of yoghurt fermented with Lactobacillus delbrueckii ssp. bulgaricus OLL1073R-1. Br J Nutr 104: 998-1006.

79. Merenstein D, Murphy M, Fokar A, Hernandez RK, Park H, et al. (2010) Use of a fermented dairy probiotic drink containing Lactobacillus casei (DN-114 001) to decrease the rate of illness in kids: the DRINK study. A patient-oriented, double-blind, clusterrandomized, placebo-controlled, clinical trial. Eur J Clin Nutr 64 669-677.

80. Rerksuppaphol S, Rerksuppaphol L (2012) Randomized controlled trial of probiotics to reduce common cold in schoolchildren. Pediatr Int 54: 682-687.
81. Río ME, Zago Beatriz L, Garcia H, Winter L (2002) The nutritional status change the effectiveness of a dietary supplement of lactic bacteria on the emerging of respiratory tract diseases in children. Arch Latinoam Nutr 52: 29-34.

82. Cobo Sanz JM, Mateos JA, Muñoz Conejo A (2006) Effect of Lactobacillus casei on the incidence of infectious conditions in children. Nutr Hosp 21: 547-551.

83. Smith TJ, Rigassio-Radler D, Denmark R, Haley T, Touger-Decker R (2013) Effect of Lactobacillus rhamnosus LGG(R) and Bifidobacterium animalis ssp. lactis BB-12(R) on health-related quality of life in college students affected by upper respiratory infections. Br J Nutr 109: 1999-2007.

84. de Vrese $M$, Winkler $P$, Rautenberg $P$, Harder $T$, Noah $C$, et al. (2005) Effect of Lactobacillus gasseri PA 16/8, Bifidobacterium longum SP $07 / 3$, B. bifidum MF 20/5 on common cold episodes: a double blind, randomized, controlled trial. Clin Nutr 24: 481-491. 